\title{
Traditions of American Education
}

\author{
Sol Cohen \\ University of California at Los Angeles
}

Diane Ravitch, Left Back: A Century of Failed School Reforms. New York: Simon \& Schuster, 2000. Pp. 544.

In the ... debate over canons, tradition has been cast as a conservative idea. [But] that we have intellectual and moral ties to the dead is neither a conservative nor a radical idea. It is simply true that contemporary ideas and values are best understood in relation to a history of arguments and a long succession of choices and of dissenting opinions. Knowing the history enhances our self-understanding. (Michael Walzer, "Philosophy, History, and the Recovery of Tradition," The Cbronicle of Higher Education, 16 June 2000, 56.)

In 1962, Frederic Lilge, professor of philosophy in the Department of Education, University of California, Berkeley, and a well-known critic of progressive education, published a sympathetic review of Lawrence A. Cremin, The Transformation of the School: Progressivism in American Education, 1876-1957. At the end of his review, Lilge posed a challenge: "whether a complementary volume might not now be written setting forth what might be called the conservative tradition in American educational thought." Lilge went on briefly to depict both traditions. In the progressive tradition, "education is distinguished by the broad, almost unlimited, social responsibilities it placed on the shoulders of educators." In the conservative view, "the school is regarded as a place serving primarily, though not exclusively, the development of the individual's intellectual capacities."' Invited to respond, Cremin wrote:

I concur wholeheartedly in Lilge's proposal for a complementary study of the conservative tradition in American educational thought. Such a study would fill some embarrassing lacunae in our historical thought-how much, after all, do we really know about William Torrey Harris or Irving Babbitt, or Robert M. Hutchins, or Isaac Kandel. ${ }^{2}$

Diane Ravitch's Left Back: A Century of Failed School Reforms (the sub-title would be, more accurately, "A Century of Failed Progressive School Reforms") is part history and part strong critique of progressive education reform

'Studies in Philosophy and Education 2 (1961-1962): 63-5.

${ }^{2}$ Ibid., 65. 
movements of the twentieth century. Students of the history of American education, and of Ravitch's extensive oeuvre, will be familiar with the main outlines of her critique of progressive educational thought, but will not have encountered it in such detail, and in one place.

Left Back offers much more. At last, almost 40 years after Lilge presented his challenge, Ravitch has undertaken to write that history of the conservative tradition in educational thought and to fill some embarrassing lacunae in historical thought about American education. ${ }^{3}$ It is worth observing that although Ravitch's stance hardly differs from Lilge's of 1962, she resolutely refuses to accept the term "conservative." Her terminological discomfort is unmistakable. She calls that tradition variously the "liberal" tradition or the "liberal arts" tradition or the "academic" tradition, or simply "traditional" education. Why not call a spade a spade? Conservative (small " $c$ ") education, as a way of thinking about education, an ethos, a language of discourse, is the honest label of convenience. Unfortunately, common usage, at least in professional education circles, has reduced the term to an insult or an epithet. "Meaningful dialogue between the "conservative" and progressive traditions would be too much to hope for today; meaningful dialogue between the "liberal" and progressive traditions may be a possibility. Although I find it awkward, I will go along with Ravitch here, and refer throughout to the "liberal" tradition in education.

The liberal and progressive traditions in education are rival and antagonistic traditions, and have been for a century. The liberal tradition dominated American education in the closing decades of the nineteenth century until about the World War I period, when it was displaced by progressive education, hegemonic up to this moment. If history is written by the victors, it has been written largely by defenders and promoters of progressive education. Life was made difficult for those educators who dared to criticize progressive education. In the decades 1920-1950 the liberal tradition almost disappeared from public discourse. It was kept alive through the decades by a small group of scholars whose voices are held only in dim memory, if remembered at all. Ravitch seeks to restore to the history of education the champions of the liberal tradition whom she calls "apostles of liberal education," among them Harris, Bagley, Kandel, and Hutchins, but also Charles W. Eliot, W.E.B. DuBois, Michael Demiashkevitch, Alexander Meiklejohn, Paul Shorey, and William C. Bagley_-"whose ideas were balanced and sound, if not heeded, and whose philosophy remains central to the reconstruction of American education today," and who have been flatly dismissed or ignored in most histories of American education. (16) I would have preferred the whole books to have been

${ }^{3}$ Cremin had the chance to do it himself in his trilogy American Education (New York: Harper \& Row, 1970-1988), but declined.

${ }^{4} I$ avoid the dilernma in my "The Influence of Progressive Education on School Reform in the United States: Redescriptions" in Challenging Orthodoxies: Toward a New Cultural History of Education (New York : Peter Lang, 1999) by distinguishing between the progressive tradition and the "moral-intellectual" tradition in education. 
devoted to the life, thought, and works of the "apostles." But Ravitch whets our interest in this large, minimally explored subject.

Ravitch has never been an ivory tower historian of education. She produces near a book each year, yet retains the kind of engagement with, and passionate commitment to public education that characterized the new history of education of the 1970s and that is rare today. Indeed, in Left Back, Ravitch finds herself revising assumptions she had previously held, an experience scarcely ever acknowledged by historians of education, or other scholars. Among historians of American education, Ravitch is not only the most trenchant critic of progressive education, but the most widely known advocate of the contemporary "excellence" or "standards" school reform movement. The public debate on the crisis in public education in the United States has so far largely restricted itself to matters internal to education: testing, teacher training and certification, salaries, and the like. But ideas, as Ravitch's mentor, Lawrence Cremin, explained, may have more enduring consequences. Ideas are

moving forces that operate within a social context, that compete for attention, and that profoundly effect what people believe is possible and desirable in the realm of education.

This is the presentist thrust of Left Back. Present-day theorists and advocates of standards-based school reform like William J. Bennett, Chester Finn, Theodore Sizer, E.D. Hirsch, Jr., and Ravitch herself, are heirs of a century-old tradition now marginalized or forgotten. Ravitch aims to re-familiarize readers with that tradition and to restore it to the public conversation. Left Back is written in a pellucid style and is intended to appeal to a broad readership. ${ }^{6}$

The main narrative line of development in Left Back can be described briefly. If Ravitch's The Troubled Crusade: American Education, 1945-1980 (1983) was a first report card on American education, Left Back: A Century of Failed School Reforms is a second, more disturbing report card. The "crusade against ignorance" is now more than troubled; it has failed. Left Back is a story of unrelenting attacks on disciplined training of the mind and the academic mission of the high school, always masked in the linguistic mystification of empty slogans, cliches, and metaphors about "democracy," "growth," and "meeting the needs" of children and youth. The public schools lost "their anchor, their sense of mission, their intense moral commitment to the intellectual development of each child."(16) Ravitch makes a strong case for the triumph of progressive education as a tragedy for American education, for culture, and for the polity. The legacy of progressive education was a levelling of public secondary education deeply prejudicial to the interests of the poor, people of colour, and the culturally disadvantaged. In the liberal tradition of education, Ravitch finds an alternative set of ideas and values

${ }^{5}$ Lawrence A. Cremin, American Education: The Metropolitan Experience, 1876-1980 (New York: Harper \& Row: 1988), 10.

${ }^{6}$ Left Back has been widely and not unsympathetically reviewed. See Sol Stern in Commentary 110 (2000): 53-5; Herbert Kohl in Los Angeles Times Book Review, 10 September 2000, 3; Nicholas Lemann in The New Yorker, 25 September 2000, 89; Sara Mosle in New York Times, 27 August 2000, and Alan Ryan in New York Review of Books, 22 February 2001, 18-21. 
that provide a rationale for the development of intellect and the formation of character which students gain when held to high standards of achievement in course work centred on serious academic subject matter. Of course, the liberal tradition can be faulted, and Ravitch does fault it. Nevertheless Ravitch, in the struggle to attain the ideal of social equality, stands on the side of Matthew Arnold: "The men of culture are the true apostles of equality... a true source, therefore, of sweetness and light."

In her first two chapters, "The Educational Ladder" and "A Fork in the Road," Ravitch sets the stage nicely, laying out the main tenets of late $19^{\text {th }}$ century liberal tradition, the "before" to the progressives" "after": a complex of ideas about democratic education, education in a democracy, equality of education, the "educational ladder," and the liberal arts curriculum. Such scholars as philosopher William Torrey Harris, U.S. Commissioner of Education, and Charles W. Eliot, president of Harvard University were among its most articulate champions. The classic text, the key document in the liberal tradition is the National Education Association Report of the Committee of Ten on Secondary School Studies (1893), which brought Harris and Eliot together.

The Committee of Ten stood for an ideal of education aiming to develop the intellect or the "mental faculties," to strengthen character or "discipline the will," and to transmit the "wisdom of the past." It was assumed the subjects best suited to realize the ideal in the classroom were the traditional subjects of the liberal arts curriculum, expanded to include English literature and modern foreign languages, and the natural sciences. Here was a curriculum that would develop "the powers of observation, memory, expression and reasoning." Whatever the particular subjects to be studied, the aim would be the same for all students: all needed "strong and effective mental training." It was considered a curriculum that would best prepare those youth who were willing and able to pursue it to continue their education in college or university, and that would best prepare those students not college-bound with the knowledge and skills required for democratic citizenship and an economically productive life.

One source of information about late nineteenth-century American education, the commentaries of European visitors, has yet to be fully utilized by historians of American education. Those commentaries would buttress Ravitch's version of the "before." The American public school experiment was well known to English, French, and German observers of American education. They were impressed with the intellectual seriousness of its goals and objectives. They noted especially the immense importance Americans attached to education as an avenue of mobility, and their commitment to the ideal of equality of opportunity. To Sir Michael Sadler, the most perspicacious of all European observers of American education, the supreme objective animating American education was an intense belief in the rightness of giving to every boy and girl in the community, so far as possible, an equal chance to make the most of his or her natural powers. This explained the widespread provision of free, public high schools, and the uniquely American 
"ladder" system of organization, with the rungs of the ladder leading, in many states from the kindergarten to the university.

Americans were opposed to early selection for future careers or occupations as was the custom in Europe. The ladder system opened the doors of opportunity for higher education to all who sought it. This was why all youth received an education in academic subject matter.

There were blemishes: the ideal of equal opportunity was far from being achieved in practice, especially in the Southern states. And European visitors were put off by the regimentation and harsh discipline in American classrooms and teachers' reliance on drill and rote memorization. Still, they universally acclaimed America's system of public education as the most democratic in the world.?

Not all Americans agreed. The prominent child study expert and psychologist of adolescence, G. Stanley Hall lead the opposition. The Committee of Ten report especially offended him. When Eliot responded, their exchange became memorable, and the most memorable part of their exchange warrants emphasis. Hall rejected the idea of an educational ladder and ridiculed the idea that all high school students should receive an academic subject matter education. Hall pointed to the "great army of incapables" in the high schools. A "democratic" education demanded sorting and "differentiation" according to students' probable destinations in life. Eliot answered: "We shall not know until we have tried what proportion of children are incapable of pursuing" an academic program. We Americans "habitually underestimate the capacity of pupils at almost every stage of education." Eliot continued: "The classification of pupils according to their so-called probable destinations, should be postponed to the latest possible time of life." Where Europeans are accustomed to classifying and sorting children early in their life as future peasants, mechanics, trades people and professionals, and giving them an education appropriate to their future role, "this was not the American way." And who had the right to make these "prophecies" about children? Eliot said that in a democratic society children had the right to the best education according to their own talents and ambitions. As for Hall's claim that the high school population included a "great army of incapables," Eliot countered: "Any school superintendent or principal who should construct his programs with the incapables chiefly in mind would be a person professionally demented." (46-7)

The Committee of Ten, Harris, and Eliot thought they were ushering in a new era in American education, in retrospect they ushered out the old. By 1910, certainly by 1915 , the report of the Committee of Ten had taken on an odour of obsolescence, and Eliot and Harris had become objects of scorn: anathematized as old-fashioned, "conservative," and worse, undemocratic, aristocratic, and elitist by leaders of a militant progressive education movement beginning to hit its stride.

'Michael Sadler, "Impressions of American Education," Educational Review 25 (1903): 217-31; Michael Sadler, "Some Points of Contrast in the Educational Situation in England and America," Educational Review 24 (1902): 217-27; David Salmon, "Impressions of American Education," Educational Review 18 (1899): 437-50; C.S.H. Brereton, "A Birds-Eye View of American Education," Monthly Review 5 (1901): 57-68. 
In 1893 the high school was the rung of the educational ladder that prepared youth for college or for the "duties of life" through rigorous study of academic subject matter. By 1918, progressives had injected into the mainstream of American educational thought the idea that high school would prepare students for life, but without ever mentioning either development of intellect or study of academic subject matter. The classic document is another NEA report, the Report of the Commission on the Reorganization of Secondary Education (1918). The report consummated, at least in theory, a revolution in American secondary education. Its publication marks the defining moment in what I would term the first transformation of American secondary education: the shift from a college preparatory institution to a terminal, custodial institution. It set the progressive agenda for secondary education for another thirty years.

The Commission rejected the idea of training of intellect and study of formally organized academic subject matter as the goal for American secondary education. In the latter's place it substituted the seven "cardinal principles" of secondary education: "health, command of fundamental processes, worthy home membership, vocation, citizenship, worthy use of leisure, ethical character." Underlying the "cardinal principles" and the proposed re-organization of secondary education was a conception of the high school as a legatee institution or surrogate parent, and secondary education as simply the prolongation of elementary education, an education for the re-socialization of youth. It was not, of course, defined for the public as such. The promulgation of the Cardinal Principles was acclaimed by advocates as the liberation of American youth from the old, "aristocratic" tradition of education, and the herald of a new, "democratic," American education. How can so radical an ideological turn, from a conception of the high school as a college preparatory institution to a conception of the high school as a terminal institution, be explained? Clues are scattered throughout the first part of Left Back. I want to isolate three circumstances that precipitated the turn, and decided the direction it took: the rise of mass public secondary education, the invention of progressive education theory, and the professionalization of education.

The decades 1890-1920 witnessed the rise of mass public secondary education. The mass public high school may not have been able to continue along in the way advocated by Eliot and the Committee of Ten, emphasizing disciplined training of the mind and mastery of academic subject matter, but the direction secondary education would take was not foreordained. As Foucault notes, adolescents never appear in the wild state, they are always in period costume. Which is to say two things: whatever else it is, the idea of adolescence is a cultural idea, a humanly created category, a construction, and no school system is created for adolescents about whom one doesn't have some preconceived notions about their character, their intellectual capacities, and their proper place in life.

Progressive educators created the new secondary education with a particular notion of the high school's clientele in mind. At the turn of the century, the net of an ever more stringently enforced compulsory education brought into high 
schools a large, heterogeneous population, many sons and daughters of recent immigrants, many from poor, culturally distinct homes, who were to be kept in school as long as possible. This population posed new problems for American educators. Hardly had they made their appearance than professional educators concluded, as did Hall, that high schools were largely populated by "incapables" for whom the traditional content and purpose of secondary education was inappropriate and irrelevant. This bleak perception of the high school population reflected, among other things, the widespread anti-immigrant sentiment of the time. The eminent Stanford University professor of education Elwood P. Cubberley viewed the immigrants from southern and eastern Europe as "largely illiterate, docile, lacking in self-reliance and initiative, and not possessing the Anglo-Teutonic conceptions of law, order, and government." Their coming, he continued, "has served to dilute tremendously our national stock, and to corrupt our civic life." Jaundiced perceptions of the high school population were legitimated and exacerbated by the "science" of psychology, as exemplified by the new IQ testing enterprise, which promoted what Ravitch calls a "brutal pessimism" about student's intelligence. The liberal idea of an educational ladder began to seem preposterous to some educational leaders. This is Dean James $\mathrm{E}$. Russell of Teachers College, Columbia University, in 1906:

We boast of an educational ladder that reaches from the gutter to the university, and we see nothing amiss in making our elementary schools preparatory to the high school, and the high school preparatory to the college and university. In other words, that which few need all must take. No other great nation that I know of thinks it worth while to train everybody for everything -and nothing! [sic] —and to do it at public expense. (95)

If we consider the liberal tradition in education as a chain of ideas about mental discipline, faculties of the mind, equality of opportunity, the educational ladder, and the learned branches of knowledge, link by link, the chain was dismantled by progressive educationists like Russell, Hall, Lewis Terman, Edward. L. Thorndike, Elwood P. Cubberley, David Snedden, Franklin Bobbitt and pre-eminently, the ubiquitous John Dewey, the public face and public voice of progressive education through the decades. Dewey frankly avowed his hostility to the liberal tradition in education and his works provided much of rhetoric with which progressives attacked that tradition. He saw that tradition as elitist, aristocratic, book-ridden, and much more, and provided ideas (and metaphors and slogans) to justify the progressive agenda: "growth," "learning by doing," "activities, "reconstruction of experience," "occupations," "interest," "needs," "embryonic community." As James B. Conant observed, if John Dewey hadn't existed, he, or his doctrines, would have had to be invented. ' Ravitch is surprisingly indulgent where Dewey is concerned. She makes excuses for Dewey: the "progressive education movement was inspired by Dewey's writings [but it] was not always strictly loyal to Dewey's inten-

${ }^{8}$ Changing Conceptions of Education (New York: Houghton Mifflin, 1909), 14.

${ }^{9}$ The Child, The Parent and the State (New York: Macmillan, 1959), 93-4. 
tions."(59) Ravitch provides enough evidence, however, for readers to take a much less appreciative view of Dewey's intentions.

In and after the World War I period, mass public secondary education was not so much transformed as created, and the professional educator and the professor of education came into their own. To a generation of educational leaders that came of age in the World War I period, the future direction of public secondary education would not be left to college and university presidents or college and university faculties, it would be controlled by an autonomous profession of education. The creation of a system of mass secondary education for America would not be an extension of the academic tradition inscribed by Eliot and the Committee of Ten. It would be different in function, it would have its own philosophy, its own experts and canon of authorities, its own curriculum, its own language of discourse, its own teacher-training institutions.

The new philosophy of education and a "science" of education would be shaped at institutions of higher learning like the University of Chicago, Teachers College, Columbia University, University of Illinois, and Stanford University. Slowly but surely, and indelibly, the meaning of equality of opportunity, education for democracy, and democratic education were re-defined. Progressive thinkers argued that a high school that offered the same curriculum to all was "anti-democratic," while a school with differentiated educational programmes was "democratic." Requiring all students to take subjects that prepared for college was "elitist," preparing children and youth for their future occupation through an "appropriate" education was "democratic."

Equality of opportunity was also redefined. Formerly equality of opportunity meant the right of all who might profit from an academically-oriented secondary education to enjoy its benefits to the limits of one's abilities. Now equality of opportunity meant simply the right of all who came to school be offered something of value. ${ }^{10}$ Another legacy of the Cardinal Principals is this. Increasingly, college and university liberal arts faculties turned away from public secondary education, which they saw as the domain of a strange kind of academic. Education professionals were happy to see them withdraw. The field of education was left to the professionals with little authoritative criticism or opposition, an isolation which only began to end in the late 1940 s.

${ }^{10}$ Lawrence A. Cremin “The Revolution in American Secondary Education, 1893-1918," Teachers College Record 57 (1955): 303. 
IV

The transformation of the public high school into a terminal institution, formulated in the realm of progressive thought and proposal, had still to be achieved in practice. An older generation of high school teachers and principals had to be converted to the new way of thinking about education, and there were also parents who had to be re-educated. Progressives relentlessly pressed ahead. The decades 1920-1950 witnessed a ceaseless flow of activity. New organizations came into existence to take up the cause: Progressive Education Association, American Council on Education, Educational Policies Commission, American Youth Commission. New schools were established to demonstrate the goodness of progressive education: Lincoln School, the Dewey School, the Organic School. New ideas and new slogans came one upon the other: creative self-expression, project method, activity leading to further activity, social reconstruction, core curriculum, integrated curriculum, meeting the needs of youth, social adjustment. There were new faces to defend and proclaim the progressive in education: W.W. Charters, William H. Kilpatrick, Harold Rugg, L. Thomas Hopkins, Caroline B. Zachry, and others. Always, when needed, Dewey was available.

Progressives called for the gutting of the liberal tradition of education in the name of "democracy" and "science." Educators who disagreed with progressive school reform ran the risk of being branded defenders of the old, aristocratic, elitist, anti-democratic education tradition. Still; there were a few "apostles of liberal education" who went public. William Maxwell, Superintendent of Schools, New York City, was one of the rare schoolmen to speak up for tradition and to stand up to the professional education establishment.

Ravitch makes a surprising addition to the company of the "apostles," the black scholar and activist W. E. B. DuBois, who argued against special vocational training as the appropriate education for black children, and in defence of liberal, intellectual education. Sounding like Eliot or William Torrey Harris, DuBois explained, "the object of a school system is to carry a student as far as possible in its knowledge of the accumulated wisdom of the world." When the student was no longer able to pursue his learning for whatever reason, vocational education could follow. William C. Bagley, first at the University of Illinois, then at Teachers College, Columbia University (nicely depicted by Ravitch as "an exile in this expert's paradise"), could always be counted upon to challenge the validity of the "science" and "research" that supported progressive education reforms and the attacks on the academic subject matter curriculum, and to defend the liberal tradition.

In the 1930s and 1940s a few more heirs of Eliot and Harris spoke up: Isaac Kandel, Robert M. Hutchins, Mortimer Adler, and, Michael J. Demiashkevich. There are nice vignettes of all in Chapter 8, "Dissidents and Critics." The most interesting is about Demiashkevitch, who with Albert Pinkevich, Bagley, and a few others, founded the short-lived "Essentialist Committee for the Advancement of American Education." which is to say, the committee for the advancement of the liberal tradition in education. That word "essentialist" sank it. It made an easy target for Dewey and William Heard Kilpatrick, who denounced the Committee 
as a bunch of "conservatives," "fundamentalists," and "reactionaries." Hutchins' critique of progressive education and defense of the liberal tradition could not be dismissed so easily, though Dewey tried; Hutchins was "authoritarian."

Kandel, a prolific author and sharp-tongued debater (and, according to Ravitch, the "most feared dissident") dismissed the core ides of progressive education as "shallow ... superficial [and] socially regressive." Progressives, he said, threw out tradition, leaving a legacy of "nihilism and ant-intellectualism." Americans, he said, had always had a profound faith in education, but unless education was given a richer and more intellectually serious content, all that would be left of this ideal, would be a profound faith in keeping youth in school.

But neither the education profession nor the country was interested; no one was listening. If we consider the two traditions of education, the progressive and the liberal, simply as language systems, the apostles of liberal education were not only outnumbered but out-manoeuvred. Progressives appropriated the language of democracy, equality of opportunity, and the needs of youth, all the while recasting key words and concepts of the liberal tradition-intellect, mental faculties, will, character, and the wisdom of the past-as the language of reactionaries. The liberal tradition of education was at risk of disappearing as a language of educational discourse.

At this critical juncture, in the late 1940s, overconfident and careless, and thinking itself invulnerable, the professional education establishment over-reached itself in the Life Adjustment Education Movement, the apotheosis of the progressive education movement. In the spring of 1945 , in the course of summarizing the proceedings of a conference at the United States Office of Education, Charles A. Prosser, of the Division of Vocational Education, offered a resolution. He declared that the high schools were not meeting the needs of the great majority of youth. The high schools were preparing $20 \%$ of youth for college, and $20 \%$ for "desirable skilled occupations." But the needs of the remaining $60 \%$ were not being met. What did they need? In the words of Prosser's resolution, immediately dubbed a "historic resolution, " they needed a "life adjustment education." The Prosser Resolution was adopted unanimously by an enthusiastic conference. With breathtaking certainty, the majority of the nation's high school youth were written off as more or less uneducable. What kind of education did they need? An education that equipped them to "live democratically with satisfaction to themselves and profit to society as home members, workers, and citizens." Here as a United States Office of Education publication put it, was "a philosophy of education which places life values above acquisition of knowledge."

The implication that "acquisition of knowledge" has little or nothing to do with "life values" and that knowledge was of no use in solving "the real life problems of ordinary youth" was an essential premise of the life adjustment education movement. Thus the life adjustment education movement stated the proposition toward which progressive school reformers had been moving for at least three decades: that in a system of mass, public secondary education, an aca-

"Life Adjustment Education For Every Youth (Washington, D. C., n.d. [1950]), 15. 
demically serious education geared to college or to skilled employment was an impossibility for all but a small fraction of the high school population. Life adjustment education was not seen by its advocates as the ultimate surrender to the idea of the public high school as a custodial institution for the many, or the ultimate abandonment of intellectual or cultural standards. Rather, it was seen as the final repudiation of "the aristocratic cultural tradition" of education, and a "New Deal" for youth: how to prepare a budget, how to develop self-confidence, how to get along with parents, how to be more attractive, the do's and don'ts of dating, personal hygiene and grooming, how to make friends. Life adjustment education was deemed indispensable. Prosser, joined by Harl R. Douglass, Dean of the College of Education, University of Colorado, called for "life adjustment education for all American youth," which became the rallying cry of the movement. Advocates of life adjustment education saw themselves as crusaders. Ravitch charitably quotes Prosser's peroration at the First National Conference on Life Adjustment Education in full:

Never in all the history of education has there been such a meeting as this one....

Never was there such a meeting where people were so sincere in their belief that this was the golden opportunity [to] give to all American youth their educational heritage so long denied. What you have planned is worth fighting for-it is worth dying for. (331)

Ravitch lets the quote speak for itself. When the specific programs and curricula of the life adjustment education movement are long forgotten, what will stick in the mind are pronouncements like Prosser's. One cannot help but recall Eliot's rebuke of G. Stanley Hall sixty years earlier.

The life adjustment education movement was the last straw. It incited a violent outburst against progressive education. It brought out into the public arena more apostles of liberal education than ever before: Albert Lynd, Arthur Bestor, James Koerner, Mortimer Smith, to name only a few of those who roughly called into question the intellectual foundations and moral outlook of progressive education and whose activities heralded new life for the liberal tradition. ${ }^{12}$ "Excellence" became the watchword of this counter-progressive education movement. The older generation of apostles was never able to reach any broad audience for the liberal tradition in education. In the 1950s a rapidly growing group of parents, high school educated themselves and concerned about their children going on to college, provided a new audience for critics of progressive education and champions of excellence and the liberal tradition. The life adjustment education movement disappeared from the scene. By 1953 the very term "life adjustment education" was passé. The excellence movement, however, had no staying power. In the 1960 s a tide of romantic progressivism in education-recall A. S. Neill, Joseph Featherstone, Ivan Illich, Paul Good-

${ }^{12}$ The year 1953-which saw the publication of Arthur Bestor Jr., Educational Wastelands, Albert Lynd, Quackery in the Public Schools, and Robert M. Hutchins, The Conflict in Education, and Paul Woodring, Let's Talk Sense About Our Public Schools-was the annus borribilis of progressive education. In Canada, meanwhile, Prof. Hilda Neatby's So Little For the Mind (Toronto: Clarke, Irwin, 1953) became a root text of anti-progressivism. 
man, George Leonard, John Holt, Edgar Z. Friedenberg, and Herbert Kohl - simply swept it aside, only to be resuscitated in 1983.

In a concluding chapter, Ravitch discusses the contemporary standards movement in education. Ravitch differentiates between the excellence and standards school reform movements, but I find it more useful to consider them phases of the same school reform movement. That is, I find it helpful to consider the current standards school reform movement as the latest phase of a series of rumblings that began in the early 1950s and whose watchword was excellence, and which continues under the banner of the "standards" movement. The post-1983 and Nation At Risk standards school reform movement has been engaged in a struggle to restore the dominance of the liberal tradition in education and transform the high school from a mass, public, terminal institution into a mass, public, college preparatory institution.

This second transformation of the secondary school will be more difficult than the first transformation of the high school. The first transformation of required only the creation of new institutions. The second transformation of the high school requires not only the transformation of institutional structures but a transformation in the assumptions, core beliefs, and philosophy of the professional education establishment. The standards school reform movement has the momentum. Whether it will succeed in imposing its outlook and values in any enduring way, or suffer the same fate as the excellence movement of the 1950 s, is not at all sure.

V

Ravitch finds much to lament in Left Back, but she ends on a hopeful note. Ravitch never challenges the notion that the public high school should be the universal experience of youth in America. She is committed to the public school idea. She believes that if Americans are to reclaim the public high schools as centres of learning, they must understand the history of school reform in the twentieth century. This may be called "history hope." Left Back may indeed lead readers to a greater understanding of the failure of progressive education and thus to a greater understanding of how the public schools have come to their present situation. But Left Back also implicitly reveals the constraints on any change the advocates of the liberal tradition in education and the standards-based school reform party might want to bring about.

Can the liberal tradition be re-appropriated in American public education in any effective and enduring way? The answer to this question depends on the answer to another question: can educationists transmute their core beliefs and philosophy? I think it unlikely. The Progressive Education Association died a long time ago. But progressive education as a belief system is a very lively cadaver. It undergirds educational policy and practice, and it is entrenched in the education profession. The professional education establishment is an establishment highly skilled in bureaucratic manoeuvring and self-protection. It may for tactical reasons agree to, or even initiate, liberal school reforms, but the culture 
of professional education remains "progressive." It is committed to promote and to defend progressive education.

There is an audience of undecided parents and the informed public, who must be won over to the standards party. My study of the mental hygiene movement and the "medicalization" of American education, indicates that a large, if unquantifiable, segment of parents and the public is sympathetic to having mental hygiene concepts and values inform teaching and school policy and practice. ${ }^{13}$ The therapeutic ethos of the mental hygiene movement is opposed to everything the standards school reform movement represents and is constantly exerting pressure on the latter. The challenge of the "medicalization" of American education has yet to be confronted in any meaningful way by the standards school reform party.

Finally, Ravitch sees cause for optimism in recent developments in education research, which may sustain the liberal tradition and the standards-based school reform movement. Here too I am sceptical. Education researchers and other scholars in teachers colleges and university schools and departments of education are over-invested in the idea of change and the philosophy of the new. The last thing specialists in education can afford is to be caught purveying the old, or the traditional wisdom. Specialists in education must be constantly discovering new techniques, new bodi es of knowledge, and new truths (which, by definition, with the passage of time automatically become outdated). In any event, thanks to Ellen Condliffe Lagemann's An Elusive Science: The Troubling History of Education Research, we now have a sobering understanding of the education research enterprise and the political thicket in which it is carried on, and which leaves very little room for optimism about any long-term contribution of education research to the resurgence of the liberal tradition. ${ }^{14}$

Left Back is a one-hundred-year history of educational ideas in a century of American history. This is a very ambitious and broad task. Given the variety of ways the liberal tradition and the progressive tradition in education have been construed or employed, it is difficult for Ravitch not to be reductive about them. But what is lost in depth is gained in breadth. Left Back is an extremely important, endlessly provocative, and necessary book. It is a long overdue contribution to the history of American education and essential reading for everyone interested in the future of public education in America.

${ }^{13}$ For example, take the concern for healthy development of student's personality. This concern has its correlate in the fear that enforcement of academic standards means students failing or being held back. The notion of failure as psychologically damaging is deeply embedded in the consciousness of American parents and the public, and cannot be simply wished or argued away. The current furor over "social promotion' is but the tip of the iceberg. Sol Cohen, "Every School a Clinic: An Historical Perspective on American Education" in Cohen and Lewis C. Solmon, eds., From the Campus: Perspectives on the School Reform Movement (New York: Praeger, 1989).

${ }^{14}$ Chicago: University of Chicago Press, 2000. 